Ciência e Natura, Santa Maria, v. 37 part 2, 2015, p. 01-07 Revista do Centro de Ciências Naturais e Exatas - UFSM

ISSN impressa: 0100-8307 ISSN on-line: 2179-460X

\title{
A model of the decision making on the basis of ratios profitability and leverage
}

\author{
Bahareh Azami ${ }^{1}$, Naser Izadinia ${ }^{2}$, Daryosh Mohamadi Zangirani ${ }^{3}$ \\ MA Student, Department of Accounting, Khorasgan Isfahan branch, Islamic Azad University, \\ Isfahan, Iran \\ PhD Associate Prof. , Department of Accounting, University of Isfahan, Isfahan, Iran \\ PhD Prof. Department of Management, University of Isfahan, Isfahan, Iran
}

\begin{abstract}
This study presents a model for performance decisions based on the ratios profitability and leverage .Decision Making is whether the correlation between the bank's top 12 banks in the two DEA models and TOPSIS ratios profitability and leverage as well as the top of the 68 companies profitability and leverage there, Because recent research has been little attention to this issue. The purpose of this study, applied the analytical descriptive method After tests results showed that the top bank in terms of performance and top company in terms of performance and profitability of all companies with leverage ratios, the correlation was significant at 95\% And the resulting ranking of banks was the result of the work of other researchers in the last hypothesis, a comprehensive model for all companies based on TOPSIS method was introduced.Abstract here Abstract here Abstract here Abstract here Abstract here Abstract here Keywords: relative performance, DEA, the performance, Dependent companies and sub, TOPSIS
\end{abstract}




\section{Introduction}

B anks are financial institutions whose assets are collected from multiple sources and provide them with the parts that need liquidity, so banks are therefore an important part of each country and Investment in other business units a common tool for expanding the scope of opportunities or activities of a business unit. Where such specific relationship between one investor and is invested unit or a business unit invested subsidiary or an affiliated entity. Invested for a unit known as commercial units should be substantially influence its investment unit. It also appears that banks have an incentive to make efficient use of limited financial resources and the efficient use appears in the form of increased profitability. In today's environment in which banks operate are growing and highly competitive environment, banks continue to have to compete with several factors at the national and international expansion of activities at new investments. Investment banks need financial resources, but financial resources and their use should be well defined so that banks can be profitable [1]. It goes on to note that the analysis of financial ratios to assess the financial companies has a long history and the limitations are not a good guide for investors, creditors and managers of business units, the DEA technique can overcome the problem in fact this technique by considering the number of ratios as input and output of all proportion to the number as a measure in the name of "efficiency" is translated [2]. DEA for similar units and for the re-evaluation of similar and dissimilar TOPSIS been raised of the importance of profitability and leverage ratios for banks and companies by the Central Bank experts were selected to assess performance This suggests that the relative efficiency and top performance and top bank subsidiary and auxiliary Profitability and Leverage Is there solidarity As well as between all companies affiliated and subsidiary profitability and leverage ratios there is a correlation in this study addressed and solidarity between all of the companies provided discussed a model of or not.

\section{THEORETICAL AND REVIEW OF THE LITERATURE}

DEA is a mathematical programming model to evaluate the efficiency of decision-making units in which multiple input and multiple output for homogeneous units is calculated and in another definition is a technique by which you can be among a series of similar units to identify units that have the best performance and the performance of other units of measurement [3]. Farrell to measure the performance of one input and one output, and to estimate the efficiency of the agricultural sector in America compared with other countries use it. Farrell technical efficiency and allocative be considered in this regard [4]. And Charnes \& Cooper \& Rhodes and his views will provide a model with multiple inputs and outputs. The DEA was named based on the first letter of their last name was called CCR [5]. This model consists of multiple model CCR and the CCR cover model [6]. Banker \&Charnes\& Cooper change in the CCR model and BCC model changes that are relevant to assess the relative efficiency of units with variable returns to scale is presented and compared to the previous model which returns to scale constant review, and the units under and as a result the lower performance included a more comprehensive model proposed [7]. The following topsis by Hwang and Yoon was proposed in 1981. This method measures the performance of the units and this model is one of the best models of multi-criteria decision-making and it is growing. In this method, the m option by $\mathrm{n}$ indicators evaluated by this technique on the notion that the choice should be closest to the ideal solution positive and maximum distance from the ideal solution negative is assumed the desirability of each indicator is steadily increasing or decreasing [8].

Sherman and Gold (1985), the first study on the banking units of DEA in an article entitled bank management efficiency using data envelopment analysis performed. They looked at 14 branches of banks, savings America and came 
to the conclusion that the 14 branches surveyed, only 8 percent had 100 branch performance. Other causes of inefficiency as well as factors such as poor management of branch offices and operating costs is the number of employees [9].

Carlos et al. (2013) article, another called negative returns in the evaluation of the input shaft BCC using performance crossover to the relative efficiency closer they came to the conclusion that if the BCC model one input and one output is evaluating the effectiveness of negative more useful [10 ].

Rostami et al (2011), another article entitled evaluate the financial performance of banks listed on the stock exchange method using TOPSIS model DEA concluded that Bank Saderat minimum distance and maximum distance from the bank against the idea of entrepreneurship Al was [8].

Karbassi Yazdi et al (2011) article titled determine the performance of banks, based on data envelopment analysis and Shannon entropy method according to CCR model Super efficiency and Shannon entropy Bank has ranked first and export the model was the last place [11].

Tahari Mehrjerdi et al (2013) article titled Application of nonparametric analysis interval and the window as a complement to evaluate the financial performance of these two techniques to evaluate the financial performance of banks listed on Tehran Stock Exchange during the period from 2005 -2009 techniques used and the results of the Bank in the first rank relative to other banks were listed [12].

\section{HYPOTHESIS}

hypothesis 1: relative performance among the top banks profitability and leverage ratios are associated.

hypothesis 2: the highest performance, profitability and leverage ratios are associated banks.

hypothesis 3: the performance of all subsidiaries and subsidiary profitability and leverage ratios are associated

\section{MODEL}

BCC model is a nonlinear model under consideration and to assess the unit is to strip it can be done in two ways: to maximize and maintain the denominator for the inputoriented BCC multiple models to create or at least the denominator and keeping the numerator of which is the creation of the BCC output of multiple models [6]

BCC input oriented linear model:

$$
\begin{aligned}
& \underset{\text { St }}{\operatorname{Maxz} 0}=\sum_{\mathrm{r}=1}^{\mathrm{s}} \mathrm{uryro}+\mathrm{W} \\
& \sum^{\mathrm{m}} \mathrm{ViX}_{\mathrm{i}=1} \\
& \mathrm{i}=1 \\
& \sum_{\mathrm{r}=1}^{\mathrm{s}} \underset{\mathrm{i}=1}{\mathrm{uryr}}-\sum^{\mathrm{m}} \mathrm{ViX}_{\mathrm{i}}+\mathrm{W} \leq 0 \\
& \mathrm{i}=1,2,3, \ldots \ldots, \mathrm{m} \\
& \mathrm{r}=1,2,3, \ldots . . \mathrm{s} \\
& \mathrm{x}_{\mathrm{i}}=\text { input variable for a given weight } \mathrm{i}(\mathrm{i}=1,2, \ldots \mathrm{m}) \\
& \mathrm{y}_{\mathrm{r}}=\text { output for a given weight } \mathrm{r}(\mathrm{r}=1,2, \ldots . \mathrm{s}) \\
& \mathrm{V}_{\mathrm{i}}=\text { weight } \text { of the variable } \mathrm{X} \\
& \mathrm{ur}=\text { variable weight } \mathrm{Wi} \\
& \mathrm{w}=\text { free variable mark }
\end{aligned}
$$

BCC input oriented coverage:

$$
\begin{aligned}
& \text { Mine } \\
& \text { St } \\
& \sum^{\mathrm{n}} \lambda_{\mathrm{j} \mathrm{Xj}_{\mathrm{j}} \leq \boldsymbol{\theta} \mathrm{x}_{0}} \\
& \mathrm{j}=1 \\
& \sum_{j=1}^{n} \lambda_{j} \mathrm{y}_{j} \leq \mathrm{y}_{0} \quad \lambda_{\mathrm{j}} \geq 0 \\
& \sum_{j=1}^{n} \lambda_{j=1} \quad i=1,2,3, \ldots \ldots, m
\end{aligned}
$$

\section{TOPSIS}

TOPSIS algorithm techniques include:

1 - data matrix formed by $\mathrm{m}$ and $\mathrm{n}$ index options:

$\mathrm{A}_{\mathrm{ij}}=\left|\begin{array}{cccc}\mathrm{a}_{11} & \mathrm{a} \\ \mathrm{a}_{11} & \mathrm{a}_{12} & \ldots \ldots \ldots \ldots \ldots & \mathrm{a}_{1 \mathrm{n}} \\ \mathrm{a}_{21} & \mathrm{a}_{22} & \ldots \ldots \ldots \ldots \ldots & \mathrm{a}_{2 \mathrm{n}} \\ \cdot & \ldots \ldots \ldots \ldots & . \\ \cdot & & . & . \\ \mathrm{a}_{\mathrm{m} 1} & \mathrm{a}_{\mathrm{m} 2} & \ldots \ldots \ldots \ldots \ldots & \mathrm{a}_{\mathrm{mn}}\end{array}\right|$

2 - normalizing the decision matrix Like other methods of multi-criteria decision making matrix should be normal. The Matrix is available in two ways Scale.

A) using the norm: that each element of each column are divided by the square of squares 


$$
\mathrm{n}_{\mathrm{ij}}=\frac{\mathrm{r}_{\mathrm{ij}}}{\sqrt{\sum_{\mathrm{i}=1}^{\mathrm{m}_{\mathrm{ij}}} \mathrm{r}_{\mathrm{ij}}{ }^{2}}}
$$

B) The non-linear scaling

1. If all indicators are positive aspects.

$$
n_{i j}=\frac{a_{i j}}{\max a_{i j}}
$$

2. If all indicators are negative side

$$
n_{i j}=1-\frac{a_{i j}}{\max a_{i j}}
$$

c)Scale of fuzzy

$$
n_{i j}=\frac{a_{i}^{\max }-a_{i j}}{a_{i}^{\text {max }}-a_{i}^{\text {min }}} \quad L_{\text {g }} \quad n_{i j}=\frac{a_{i j}-a_{i}^{\text {min }}}{a_{i}^{\text {max }}-a_{i}^{\text {min }}}
$$

3. determine the weight of each indicator on $\sum^{\mathrm{n}} \mathrm{W}_{\mathrm{i}}=1$. In this regard, the most important indicator of a higher weight. The Matrix (v) the product of the standard values of its index weights.

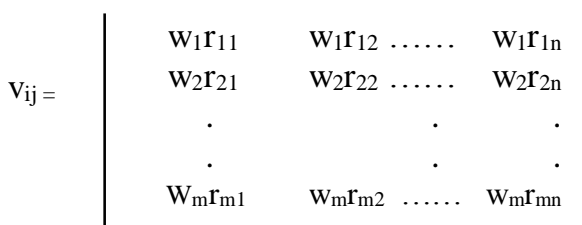

4. Calculate the ideal positive and negative so for each indicator a positive ideal $(\mathrm{A}+)$ and a negative ideal $(\mathrm{A}-)$ is calculated. 5 are the positive and negative ideas and calculate the ideal solution The ideal solution is a positive di + the ideal solution negative di- and distance option $i$ with the ideal solution both positive and negative as Euclidean calculation and the final stage of the relative closeness of options $\mathrm{i} \mathrm{cl}^{*}$ is calculated and weights will be calculated

$$
\begin{aligned}
& \left(\mathrm{V}_{\mathrm{ij}}-\mathrm{V}_{\mathrm{j}}^{-}\right)^{2}=\sqrt{ } \sum \mathrm{d}_{\mathrm{i}}^{-} \quad\left(\mathrm{V}_{\mathrm{ij}}-\mathrm{V}_{\mathrm{j}}^{+}\right)^{2},=\sqrt{ } \sum \mathrm{d}_{\mathrm{i}}^{+} \\
& \mathrm{Cl}^{*}{ }_{\mathrm{i}}=\frac{\mathrm{d}_{\mathrm{i}}{ }^{-}}{\mathrm{di}^{-}+\mathrm{di}^{+}}
\end{aligned}
$$

\section{METHODOLOGY}

Time series data type that will be tested with the software Eviews. And the software used to evaluate banks to reassess Win QSB and banks and companies in the software TOPSIS 2014 and the end of correlation is done with software Eviews version 8.

\section{Process research}

1. collect data through Kodal site;

2. Select the input and output variables of financial ratios by experts of the Central Bank;

3. Select banks and affiliated companies and their subsidiary on the stock exchange and off-exchange : 4-achieve relative efficiency DEA BCC banks through techniques based on the application of the Vienna $Q$ USB input;

5-ranked based on the highest relative efficiency in data envelopment analysis techniques; 6-re-gain performance of banks with Shannon entropy TOPSIS and weighting variables through the use of software topsis 2014; 7. The ranking is based on the highest performance of banks in TOPSIS;
8. Obtain the affiliates and subsidiary banks through Shannon entropy TOPSIS and weighting variables and use the software topsis 2014;

9. test hypotheses through the application of Eviews version number eight;

10-tabulating test the hypothesis in a nutshell; 11-analyze test hypotheses;

12. Compare the results with the results of other studies.

\section{FINDINGS}

The main hypothesis to be tested before the four banks with DEA relative efficiency and the performance of banks and companies with top banks and companies topsis were tested and found superior:

hypothesis 1: relative performance among the top banks profitability and leverage ratios are associated. The DEA Bank was selected as the Bank. In the correlation between variables in shown.

Table 1 . The main hypothesis of the first test

\begin{tabular}{|l|l|l|l|}
\hline Prob. & t-Statistic & $\begin{array}{l}\text { Profitability } \\
\text { and } \\
\text { leverage } \\
\text { ratio }\end{array}$ & $\begin{array}{l}\text { Bank } \\
\text { name }\end{array}$ \\
\hline 0.000 & 14.35 & Debt ratio & Karafrin \\
\hline 0.000 & 14.94 & $\begin{array}{l}\text { Debt-to- } \\
\text { equity ratio }\end{array}$ & \\
\hline 0.001 & 5.95 & ROA & \\
\cline { 1 - 3 } 0.000 & 16.27 & ROE & \\
\hline \multicolumn{3}{|c|}{ Source: Findings } \\
\hline
\end{tabular}

After evaluating the top-ranking DEA Bank acquired the 12 banks with the highest attention to the correlation between the relative performance of banks (Karafrin bank) there is a 
correlation with profitability ratios and the probability of $t$ less than $5 \%$ confirms this claim.

hypothesis 2: the best performance of banks profitability and leverage ratios are associated. In TOPSIS Bank as the bank was selected.

Table 2. The second hypothesis

\begin{tabular}{|c|c|c|c|}
\hline Prob. & t- Statistic & $\begin{array}{c}\text { Profitability and } \\
\text { leverage ratio }\end{array}$ & $\begin{array}{c}\text { Bank } \\
\text { name }\end{array}$ \\
\hline 0.01 & 3.76 & Debt ratio & \multirow{2}{*}{ Melat } \\
\hline 0.04 & 2.69 & $\begin{array}{r}\text { Debt-to-equity } \\
\text { ratio }\end{array}$ & \multirow{2}{*}{ ROA } \\
\cline { 1 - 3 } 0.04 & 2.72 & ROE & \\
\hline 0.002 & 5.91 & \multicolumn{2}{|c|}{} \\
\hline
\end{tabular}

After evaluating the topsis Bank has ranked the nation's top 12 banks. According to the correlation between best performance of banks Melat there is a correlation with profitability ratios and the probability of $t$ less than $5 \%$ of the claims are verified.

The main hypothesis 3: the performance of all subsidiaries and subsidiary profitability and leverage ratios are associated with.

After evaluation of subsidiaries and branches in TOPSIS, solidarity, profitability and leverage ratios solidarity with all of them and then consider a model for this correlation significant.

Source: Findings

Table 4 . The third hypothesis testing

\begin{tabular}{|c|c|c|c|c|c|c|c|c|}
\hline R-squared & $\begin{array}{l}\text { Durbin- } \\
\text { Watson }\end{array}$ & $\begin{array}{l}\text { Prob (F- } \\
\text { statistic) }\end{array}$ & F-statistic & Prob & t- Statistic & Coefficient & $\begin{array}{l}\text { Profitabili } \\
\text { ty and } \\
\text { leverage } \\
\text { ratio }\end{array}$ & $\begin{array}{c}\text { Company } \\
\text { Name }\end{array}$ \\
\hline \multirow{5}{*}{0.98} & \multirow{5}{*}{1.62} & \multirow{5}{*}{0.00} & \multirow{5}{*}{1538.43} & 0.00 & 0.19 & 23.04 & Debt ratio & \multirow{5}{*}{$\begin{array}{l}68 \\
\text { companies }\end{array}$} \\
\hline & & & & 0.00 & 0.007 & 26.50 & $\begin{array}{l}\text { Debt-to- } \\
\text { equity } \\
\text { ratio }\end{array}$ & \\
\hline & & & & 0.00 & 0.20 & 34.58 & ROA & \\
\hline & & & & 0.00 & 0.25 & 24.72 & ROE & \\
\hline & & & & 0.00 & 0.01 & 4.17 & C & \\
\hline
\end{tabular}

Source: Findings

According to the correlation between all the banks' profitability ratios Vahrmy there is a correlation.

And with the addition of a single variable debt ratio, efficiency in size 0.19 increases. And in increments of one variable debt-to-equity ratio, efficiency in size 0.007 increases. And in increments of one variable ROA, performance is increased to 34.58. And in increments of one variable ROE, efficiency increases to 4.17. This hypothesis can be made according to the following model results.

\section{Equation:}

TOPSIS $=\mathrm{C}(1)^{*} \mathrm{~B}+\mathrm{C}(2)^{*} \mathrm{BH}+\mathrm{C}(3)^{*} \mathrm{ROA}+$ $\mathrm{C}(4)^{*} \mathrm{ROE}+\mathrm{C}(5)$

\section{Of the factors in the equation:}

TOPSIS $=0.19^{*} \mathrm{~B}+0.007^{*} \mathrm{BH}+0.20 * \mathrm{ROA}+$ $0.25^{*} \mathrm{ROE}+0.01$

Another consideration is the assumption that the regression errors independence( the difference between the actual values and the values predicted by the regression model) from each other if they reject the hypothesis of independence of errors, and errors may be correlated with regression Does not exist. In order to evaluate the independence of the errors of each of the Durbin-Watson test are used. The Durbin-Watson statistic that showed no 
correlation 1.62, which is another of the assumptions of regression residuals show.represent the extent of the dependent variable that is explained by the independent variables. Adjusted coefficient means that the explanatory variables explain 98 percent of variance in the dependent variable. In order to compare the actual value with the forecast model diagram is shown below.

Graph 1 compares the actual value with the prediction model
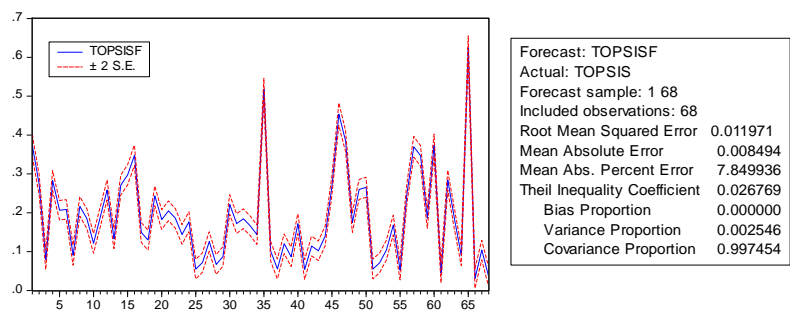

Source: Findings

The root mean square error of prediction error is related to the standard deviation, respectively, 0.01 and 0.00 and is the absolute error rate to an average of 7.84 and the coefficient of inequality oil for comparison models between zero and one, and the lower value indicates a better fit are here 0.02 is the ratio bias variance and covariance, respectively, the distance average predicted values from the mean of the observed variance The predicted values of the variance of the observed values and the residual value forecasts show no systematic error for these three models are compared.

\section{RESULTS}

As a result of the Karafrin Bank top bank among 12 banks in terms of efficiency that this result is the result of research [8], [12] and [11]. In this study, the results of the Bank ranking The first performance was obtained. The bank also has a strong management and strategies in the bank, since the success of such words, and the saderat bank in the final ranking DEA technique was the result of the study [8] and [11] respectively.

The Banker of the causes of the melat bank success is that the most important factor that would fit as an indication of future banking industry a positive signal to the investors with the High Court's decision to apply sanctions against the bank, and the melat bank As the first private bank in Iran after a few years, managed to lift sanctions imposed on the lead melat bank in Europe in terms of the results [8] either direction. It is worth mentioning that the Bank cities last place among 12 banks received TOPSIS. And the result is that the top banks such as Karafrin Bank and melat bank with profitability and leverage ratios were correlation as well as all companies in this study were associated with levels of profitability and leverage that after investigating the circumstances a good model for the relationship between companies affiliated and subsidiary profitability and leverage ratios were raised.

\section{PRACTICAL SUGGESTIONS}

In this regard, respected managers pay more attention to their performance in the competition, and if the units are inefficient decision With regard to your reference to the level of their performance and consider the level of profitability and leverage ratios is very important to be efficient at the unit level. We hope that the results of this study help loved ones in this regard, and given that 68 companies in the study were correlated with financial ratios, we propose a model in this regard, which has ideal conditions good model.

\section{RECOMMENDATIONS FOR FUTURE RESEARCH}

- it is suggested The financial ratios and other researchers in the correlation coefficient in the model DEA or their topsis.

- Among other suggestions is putting some limitations of the model, as well as inflation.

- Other researchers may be other models such as the $\mathrm{CCR}$ and tested.

- The ones with the addition of decision variables and models to achieve considerable results.

\section{Appreciation}

Thanks to my teachers who helped me in this work.

\section{REFERENCES}

[1]Sydnorany, M. R. \& Amiry, H. \& Mohammedan, A. (2012). Causality between 
investment banks-profit, with emphasis on the regulatory structure, Research economic growth and development,2 (6): 44-11.

[2] Khajavy, Sh. \& Ghayory moghadam, A. (2010) . DEA techniques complementary to the traditional analysis of financial accounting and auditing . Review of accounting and auditing, 22 (2): 56-41. ).

[3] Cook .W .D , Seiford. L .M .( 2009). Data Envelopment Analysis DEA Thirty Years On. European Journal Of Operation Research :1-17

[4] Farell, M, J .(1957). The Measurement Of Productive Efficiency, Journal Of The Royal Statistical Society . 9 (3): 253-290

[5] Charnes .A, Cooper. W .W, Rhodes ,E .(1978). easuring the Efficiency of Decision Making Units , European Journal of Operational Research. 2: 429-444

[6] Mehregan, R. (2012) . DEA quantitative models toevaluate the performance of organizations. Tehran: Tehran University.

[7] Banker Rajiv. D, Hsihui Chang, Yi -,Kao (2002). Impact Information Technology on Public Accounting Firm Productivity, Journal of Information Systems ،16(2) :209-222

[8] Rostami, M. R. \& Ghasemi, J. \& Eskandari, F. (2011) . Evaluating financial performance of banks listed on the stock exchange. Journal of Management Accounting,4 (8): 30-19.

[9] sherman H.D , Franklin GOLD .( 1985 ). Bank Branch Operating Efficiency Evaluation with Data Envelopment Analysis, Journal of Banking and Finance: 107(6): 297315.

[10] Carlos . j. Soares de Melloa, Lidia Angulo Meza b, Juliana Quint anilha da Silveira a,Eliane Goncalves Gomes.(2013). About Negative Efficiencies In Cross Evaluation BCCInput Oriented Models, European Journal of Operational Research, Elsevier ، 229 (13) : 732-737

[11] Karbassi Yazdi, H. \& Karbassi Yazdi, A. \& Pahlavy, M. (2011) . Determines the performance of banks based on DEA and Shannon Antropy, National Conference DEA, Islamic Azad University Firozkoh ,29 and 30 july 2011: 9-1.
[12] Thary Mhrjrdy, M. A. \&Yazdi, F. \& Zarey mahmod abady, M . (2013). The use of nonparametric analysis bases and window as a complement to evaluate the financial performance of Financial Analysis, Journal of Financial Analysis Exchange,6 (19): 44-27. 